\title{
HOL(E)Y TEXTS; HOL(E)Y LIVES: \\ ON THE PSALMS AND SPIRITUALITY, WITH \\ PARTICULAR ATTENTION TO THESSALONIA \\ DEPRINCE, THOMAS MERTON AND BEAT WEBER - DESCRIBED, COMPARED AND EVALUATED ${ }^{1}$
}

\author{
Christo Lombaard \\ Christian Spirituality \\ University of South Africa
}

\begin{abstract}
Continuing from the author's previously published research track on Biblical Spirituality, in this paper three different approaches to reading the Psalms in relation to faith experience are taken into review. First, the theoretical framework for the analyses to be conducted, is presented. Then, three specific works that focus on the Psalms and faith experience, but in quite different ways, are discussed: DePrince's generally esoteric approach, Merton's more spiritual approach and Weber's exegetically-grounded approach. Each of these approaches are, in turn, described and analysed, after which comparisons are drawn to indicate similarities and differences. Based on the initially presented theoretical framework, an evaluation is offered of each of the three approaches. In conclusion, the evaluative difficulty of the interaction between Bible text and reader's faith is touched upon.
\end{abstract}

Key Words: Psalms; Spirituality; Exegesis; Interpretation; Esotericism

\section{Thither and Hither: Holiness and 'Psalmliness'}

The sense of the holy has its beginning - with each individual, at the dawn of a religious tradition, and since the traceable origins of homo sapiens itself (cf. van Huyssteen 2006) in the sense that there is an Other, ${ }^{2}$ a non-human above-human, with whom/which one

\footnotetext{
A methodological note: much effort was taken with regard to the quality control of this article amongst Spirituality scholars, Psalms scholars and by the persons whose work are discussed in the article. After presenting this article as a paper at a Spirituality conference in Johannesburg, it was e-mailed for evaluation to the persons discussed in it. In the case of Merton, † 1968, the paper was on the recommendation of Paul Pearson, Director and Archivist, of the Thomas Merton Center, Bellarmine University, Louisville, Kentucky, sent to Merton specialist (and one of his former students), Paul Quenon. In all cases the respondents were asked to evaluate whether the works discussed were treated accurately and fairly in the paper. After three requests in this regard were, however, not responded to by one of the persons discussed, Dr DePrince, the recommendations received were included in a reworked version of the paper, for presentation at a Psalms seminar in Germany, as a final round of peer evaluation.

2 I use this terminology of "the Other" despite recent objections to and refinements of its usage in culturalanthropological and sociological literature, because of the older religious tradition than the social-scientific usage of this concept. This kind of language in Theology includes perhaps most famously Barth's formulation of God as the "ganz andere" (Barth 2010 [1922]:66, 47 [as editorial footnote 4 in this Barth edition indicates, he may well have been influenced by Rudolf Otto in this formulation]). In the discipline of Christian Spirituality, Waaijman's terminological choice for "Wezer", translated as "Be-er" (cf. respectively Waaijman
} 
experiences a foundationally transformative ${ }^{3}$ relationship. Classically formulated in modern scholarship by Otto (1917 in German and 1923 in English) as mysterium tremendum, ${ }^{4}$ the intent with this formulation was to express the Transcendent foundationally re/forming the person, group and society affected by a revelatory encounter with the divine; revelatory both in the sense that the divine becomes tangible beyond all limits to presence, and that an awareness dawns of the implications in the world of this above-world (Lombaard 2015a:1-7).

From within this kind of framework, the two sides of holiness and its related expressions of spirituality (cf. especially Waaijman 2000) and mysticism (cf. especially Krüger 2006) become clear: a concrete supra-worldliness, ${ }^{5}$ and an equally real thisworldliness ${ }^{6}$. The unreservedly-related dynamics of these two 'worlds' have found expression through the Christian centuries in various ways, one of which has been engaging with the Bible as the Word of God (since at least the events reflected in Nehemiah 8 Lombaard 2015d). Such engagement is experienced, variously, as holy words that speak directly to the lives of the holy. As is well known, though, not all parts of the Scriptures have been equally beloved in this respect (Lombaard 2012a:1-26); in this sense, there have been 'holes' in the wholeness of the revelation of Scripture usually confessed to in religious circles. Whether each such instance of oversight is a 'God-shaped hole' (if a little playfulness with the title of the popular book, DeBartolo 2002, may be excused) or a case of 'absence makes the heart grow yonder', time may tell.

Especially beloved among the texts of the Old Testament that have, however, often been included in Christian faith practice, have historically been the Psalms. Among the many reasons that are given so often for this preference (to the point of academic refrain, almost to give only three, and widely divergent, examples: Delitzsch 1876:45-54, Gunkel 1917:vii and Westermann 2011:11-12), is that - again the two non-distinct "worlds" ${ }^{6}$ - so many of the experiences, both positive and negative, of life are related in these (usually) 150 poems/lyrics/songs to God (cf. also Pemberton 2014 \& Pemberton 2012). Life, in many of its dimensions, is in the Psalms related to God. In concert, the Holy One speaks to the lives of the holy ones in a way that is experienced as something central; or better: centripetal.

2000 \& 2002, but for which translation I in Lombaard 2013:116 prefer the phrase "the [great] Be-ing"), offers an alternative.

3 As I point out in Lombaard 2015c:

In the South African political landscape the term "transformation" has been commandeered into almost exclusive service in the racial and gender equality measures of the present government. Though of course transformation certainly has important dimensions of social justice to it (Fox 1982:76), in the way the term is employed within Spirituality Studies, it has more deeply-existential overtones. Transformation, understood within the agenda of spirituality, is an encounter with the Divine that brings about profound change in an individual's relationship with the Holy, to the extent that this changes his/her whole life in such a way that it touches the immediate and the broader social and other circles fundamentally too (Waaijman 2002:456-481 fleshes out these aspects in great detail).

4 Otto is associated almost by reflex with the expression mysterium tremendum et fascinans. However, he never uses this exact expression in his most famous works of 1917 and 1923 . He only approaches this formulation in 1917:98, 112, 126 and 179, and the formulation never comes as close in the 1923 publication. In work to follow on this, the history of the expression mysterium tremendum et fascinans will be traced.

5 An empiric orientation, beloved in modernism, would make this kind of statement impossible. However, the intent with the formulation here is post-secularist (cf. e.g. Habermas 2008:17-29): the experience of the encounter is so overpowering that it transcends the (usually trusted) boundaries of logic - Lombaard $2015 \mathrm{~b}$.

6 These two sides of the same proverbial coin form one reality; the analytical distinction should not be taken as implying an experienced distinction. 
The sense by believers of themselves as broken, imperfect, unworthy in the face of the divine (cf. e.g. Otto 1923:56, which he calls 'creature-consciousness' in Otto 1923:10), then yet to be addressed in the Psalms by the divine, adds to the transformational experience of the Holy/Holy Scriptures. Experiencing themselves as imperfect in the presence of the Perfect, holey humans sense wholeness in the presence of the Holy/Holy Words (cf. e.g. Caputo 1998:201-204 on Marion 1992:79-128; less philosophically and giving a brief overview of Bible, mostly Old Testament, texts: Smith 2012:1-18).

Little surprise, then, that much has been written about spirituality and mysticism related to the Psalms; keeping for the moment just to books in the first half a decade of the current millennium (for an evaluative overview, cf. Lombaard 2012:53-82):

- Brueggemann, W 2002. Spirituality of the Psalms. Minneapolis: Fortress Press.

- Eaton JH 2004. Meditating on the Psalms. Louisville: Westminster John Knox Press ${ }^{7}$.

- Firth, DG 2005. Hear, o Lord. A spirituality of the Psalms. Calver: Cliff College Publishing.

- Stuhlmueller, C 2002. The spirituality of the Psalms. Collegeville, Minnesota: Liturgical Press.

- Waaijman, K 2004. Mystiek in de psalmen. Baarn: Uitgeverij Ten Have.

Also in other academic formats, publications have touched on this and related aspects, such as, recently ${ }^{8}$ :

- Bezuidenhout, LC 1995. Perspektiewe uit die Psalms wat lig werp op die wese van die geloofsgemeenskap. HTS Teologiese Studies / HTS Theological Studies 51/3, 712-719.

- De Villiers, P 1999. The Psalms and spirituality. Old Testament Essays 12/3, 416-439.

- Endres, JC 2002. Psalms and spirituality in the $21^{\text {st }}$ century. Interpretation 56, 143-154.

- Firth, DG 2001. Stages of prayer through the Psalms. South African Baptist Journal of Theology 10, 1-9.

- Le Roux, J 2003. Augustine and the study of the Psalms. (Or: the Psalms as a book of enjoyment and as an answer to a question). Old Testament Essays 16/3:624-633.

- Sipkema, E \& Lelyveld, K 2000. De Regel van de H. Benedictus en het gebruik van de Psalmen. Een spiritualiteit van de Psalmen. Amsterdamse cahiers voor exegese van de Bijbel en zijn tradities 18:131-138.

The question arises: how does one evaluate these at times quite divergent publications? With the scholarly ideals and ideologies of objectivity not only having been found wanting, but also undesirable, and replaced with the influential paradigmatic understanding of what constitutes scholarship (Kuhn 1970 and Popper 1963; cf. Lombaard \& Froneman

This volume is part of a simplification of Eaton, JH 2003. The Psalms: A historical and spiritual commentary - with an introduction and new translation. London: T\&T Clark International.

Older works include:

- $\quad$ Sorg, R 1948. The spirituality of the Psalms. Orate Fratres XXII/12.(October 21, 1948:529-541.

- Waaijman, K 1981. Psalmen by ziekte en genezing. Kampen: JH Kok (as one example from Waaijman's series on the Psalms).

- Wölber, H-O 1976. Der Königsweg der Spiritualität. Gedanken zur Frömmigkeit aus der Bibel. Evangelische Kommentare 9/12:724-727. 
2006:151-158), it has become important within the inter-subjective nature of the scholarly enterprise that each interpretative framework be briefly explained, itself to be weighed by colleagues in the intellectual enterprise.

\section{Present Imperfect: A Methodological Note}

With an orientation to the this-wordliness-other-worldliness as an experienced unity (again, footnote 6 above), and with neither aspect trumping the other, a thoroughly historical orientation presents itself as the most viable option (as e.g. in Lombaard 2014a:472-488). This, as much with the modern 'application' of the texts to life as with the analysis of the ancient Bible texts as they came into being. Naturally, this implies highly specialised knowledge of the ancient texts in their world/s and of the manners in which these texts may be brought to bear with validity on later contexts. (That is precisely the service that Biblical Spirituality as a discipline ${ }^{9}$ intends to render - to broader society as much as to the academic enterprise.) This, not with any naivety discounting the highly interrelated aspects of the analyses of what texts (may have) meant and what texts (may now) mean (cf. le Roux 1993:35-63). The inescapable hermeneutical situatedness (cf. Thiselton 1980), as much as the self-implicatory nature of a study such as this within the field of Spirituality (cf. Liebert 2002:30-49) ought never to be ignored. We are what we are; we have become what we have been made - not meant here in a fatalist sense, but as an acknowledgement in humility that our engagement with any subject matter is never context-free.

The latter leaves open, in this contribution as much as in the whole theologicalintellectual enterprise, the intellectually mature dynamic that the interpreter be interpreted. Being right or wrong, correct or mistaken - though still viable categories of evaluation are paradigmatically more realistically to some extent supplanted by the criterion of the validity of one's understanding, as presented within a given intellectual framework. That framework, in what follows, is a historically-analytical and phenomenological orientation towards both the texts of the Bible and the spirituality of believers in its wake, with a specific view to the manifestation of impulses of faith (with Lombaard 2014a:472-488 providing an example of such an approach).

In what follows, then, three approaches to the Psalms as spiritual texts are taken into review. Quite different as these three approaches are, they share the implicit understanding that from these texts the voice of the divine for the believer may be discerned ${ }^{10}$. This shared understanding is therefore not the point under investigation here; yet, as sympathetic readings offered below, this orientation is well appreciated. Rather, the divergent ways from esoteric, to spiritual, to exegetical - are demonstrated in the three pertinent publications. The diversity we will see exhibited here, probably the point of mutual incompatibility, will give us pause to reflect on whether there are, perhaps, boundaries to hearing the divine legitimately from the Psalms. Whether there are such borderlines, or not, what could they conceivably be, and: set by whom?

\footnotetext{
9 For an overview of approaches to the discipline of Biblical Spirituality, see Welzen 2011:37-60.

10 On the complex issue of discernment, cf. Lombaard 2014b, where this tentative definition is concluded to: Discernment is the process or event of Divine-human interaction in which the Holy will on certain key matters is (sought and) conveyed to the person/s involved, usually in an everyday manner, but which may at the same time assume a raised awareness of profound magnitude. In whichever case, the person/s, their closer circles and broader society find themselves altered toward a greater state of wellbeing, living a more deeply meaningful, fulfilling life in the light of the Divine guidance (sought and) found.
} 
The three works discussed below, are:

- DePrince, T 1993. The mystical key to the Psalms. New York: The United Spiritual Temple Inc.

- Merton, T 1954. Bread in the wilderness. London: Burns and Oates.

- Weber, B 2010. Werkbuch Psalmen III. Theologie und Spiritualität des Psalters und seiner Psalmen. Stuttgart: Verlag W Kohlhammer.

\section{DePrince, The Mystical Key to the Psalms}

DePrince is alleged to be a controversial figure in his professional capacities; certainly, his writings will not find easy acceptance within academic milieux. With titles including The secrets of attracting good luck (1994) and Six lessons in crystal gazing (1986), and operating a voodoo consultancy, the observation is inescapable that his life orientation is different from the other authors discussed here. The mystical key to the Psalms (1993) is no longer available in print, but an e-version of the book is available for purchase at www.supervoodoospells.com/KeyTothePslams.htm (the misspelt 'Pslams' in the URL is relayed here accurately).

In this work, DePrince's esoteric leanings as they relate to the Psalms come to the fore quite clearly. It is namely not the text of the Psalm that is of interest: neither the historical background, nor the structure (to keep for the moment to that traditional division in South Africa - cf. Le Roux 1993), nor the meaning of the words for today (always a major concern when encountering a text), nor an inherent but secret meaning that is to be discerned by means of divine revelation, as is the case in allegorical and some forms of mystic or even numerological readings of the Bible texts. Rather, in this work (i.e. DePrince 1993), the text is a powerful totem of sorts, channeling magical powers for the sake of solving real-life concerns of the reader, or, better: the user of the Psalm.

The applications of the texts are thus highly contextual, relating to practical difficulties. This, though, not in ways that for instance a sermon would seek to 'apply the Word' anew. Rather, like a talisman, a Psalm text acts as a charm that, when 'applied' correctly - that is, to the correct issues in the correct ways - miraculously solves issues. In the Psalms, then, God does not speak, really; rather, through the Psalms, God acts magically - though this is not stated explicitly, this is the implied understanding.

The latter analysis may, even if loosely, be applied to many non-specialist cases when a Bible text is related to by someone seeking divine guidance on a matter of importance in his/her life. An example will, however, demonstrate that what we have here, with DePrince 1993, is something non-traditional: 
Psalm 1

\begin{tabular}{|c|c|}
\hline Psalm 1 - NRSV Translation & $\begin{array}{l}\text { The First Psalm For Female Problems, Problems With A } \\
\text { Pregnancy, To Control a man With Your Sexual } \\
\text { Magnetism. To Control An Abusive Mate (DePrince } \\
\text { 1993:2 - direct quotation; spelling corrected) }\end{array}$ \\
\hline $\begin{array}{l}\text { Happy are those who do } \\
\text { not follow the advice of } \\
\text { the wicked, or take the } \\
\text { path that sinners tread, or } \\
\text { sit in the seat of scoffers; } \\
\text { but their delight is in the } \\
\text { law of the LoRD, and on } \\
\text { his law they meditate day } \\
\text { and night. } \\
\text { They are like trees planted } \\
\text { by streams of water, } \\
\text { which yield their fruit in } \\
\text { its season, and their leaves } \\
\text { do not wither. } \\
\text { In all that they do, they } \\
\text { prosper. } \\
\text { The wicked are not so, but } \\
\text { are like chaff that the wind } \\
\text { drives away. } \\
\text { Therefore the wicked will } \\
\text { not stand in the judgment, } \\
\text { nor sinners in the } \\
\text { congregation of the } \\
\text { righteous; } \\
\text { for the LoRD watches over } \\
\text { the way of the righteous, } \\
\text { but the way of the wicked } \\
\text { will perish. }\end{array}$ & $\begin{array}{l}\text { For problems with a pregnancy: Write on a white piece } \\
\text { of paper the name of the unborn child. Measure a blue } \\
\text { ribbon the size of your stomach by wrapping it around } \\
\text { your stomach and back. Take this ribbon and tie it } \\
\text { around the piece of paper and read the 1st Psalm over it } \\
\text { three times. When done, light a seven-day white candle } \\
\text { and place this ribbon charm next to the candle. When the } \\
\text { candle has burned out, wear this charm next to your body } \\
\text { until the child is born. While you are wearing this charm, } \\
\text { always repeat the 1st Psalm over it each day. } \\
\text { To control a man's sexual nature: Take a brown piece of } \\
\text { paper and write the man's name on it thirteen times. Then } \\
\text { write your name over his in the sign of a X... Put three } \\
\text { drops of Dr. DePrince 'XXX Lovers Brand Oil' on it. } \\
\text { Take a red ribbon the size of his left foot and wrap this } \\
\text { up with his and your names on the paper. Light a seven- } \\
\text { day red candle and place this ribbon charm next to it. } \\
\text { Repeat the first Psalm over this charm each day until the } \\
\text { candle is burned out. Once the candle is burned out, } \\
\text { place this charm in a dark place in your bedroom. } \\
\text { To control an abusive mate: Write his name nine times } \\
\text { on a piece of brown paper and write your name over his } \\
\text { in the sign of the cross... Put this in a bottle that is mixed } \\
\text { with brown sugar and one strand of his hair. Place this } \\
\text { next to a seven-day brown candle. Light the candle and } \\
\text { repeat the first Psalm over it three times. Do this each } \\
\text { day until the candle has burned out. And when he } \\
\text { becomes abusive, shake this charm up and repeat the first } \\
\text { Psalm until he becomes calm. }\end{array}$ \\
\hline
\end{tabular}

With perhaps the most beloved Psalm, Psalm 23, too, for instance, no hint is given of any traditional understandings of its meaning. Rather, this Psalm is "To Receive Secret Information From A Dream Or Spirit" (DePrince 1993:15-16). Almost all 150 Psalms are covered in similar vein, though with some Psalms combined, usually in groups of two, but at times in larger groupings. Psalm 119 receives the most extensive attention; Psalm 134, like a few others, is given a kind of aphoristic treatment: "To Excel In Studies And Pass Tests. Repeat this Psalm daily to help you excel in your studies and pass tests" (DePrince 1993:52). Here and there, a Psalm is omitted, and, rarely, a Psalm may be employed twice. 
A brief bibliography of some esoteric works concludes this small volume, although none of the bibliographic entries are referred to in the text. Accusations of plagiarism have been made against the book as a whole (cf. Peterson 2008), which apart from the usual legal and ethical concerns, also raises questions in this case on competing/alternate concepts on text, authorship and related matters, which in non-Western, non-Modern voodoo-cultural constructions may well be construed differently. Certainly, the notions of what the Psalm texts can $d o$ and how such 'results' are effected, lie beyond Western/ised boundaries of the ordinary. Here, God works in stranger ways than the usual...

\section{Merton, Bread in the Wilderness}

Merton, the influential mid-20 ${ }^{\text {th }}$ century monk and writer had published at least twice elsewhere on the Bible (Merton 1972) and on the Psalms (Merton 1956) as they relate to faith. In these works, as in Bread in the wilderness (1953), Merton does not write about the Bible text in the sense that he offers exegeses of selected passages. He writes more hermeneutically, about what the Bible texts (can) do to its faithful readers. Spiritual reflections on the ways in which the Bible texts (may) steer faith is perhaps an accurate characterisation of his writings on this matter. Merton (1953:140) thus writes on "the spiritual sense of Scripture". Not what the Bible texts said, but how they speak is the focus now.

Merton does not shy away from the difficulty the Bible texts pose for their readers: "It is of the very nature of the Bible to affront, perplex and astonish the human mind" (Merton 1972:11). Anticipating the popular $21^{\text {st }}$ century Brueggemann (2002:24-45) analysis of the Psalms in his Spirituality of the Psalms, Merton (1972:11) continues: "Hence the reader who opens the Bible must be prepared for disorientation, confusion, incomprehension, perhaps outrage". Why then continue reading the Psalms book? Because of its "primitive sincerity and perfection", Merton (1956:7) writes; "not because it is old but because it is young"; the Psalms have a "youthful strength and directness".

Casting his "pious application of the text" in the service of the Church and mentioning by name the encyclical Divino Afflante Spiritu" (Merton 1953:140), Bread in the wilderness is presented clearly as a monk's reflection on "perhaps the most significant and influential collection of poems ever written" (Merton 1953:3). Monastic life, liturgy and Catholic orders are recurring themes; holy mass and pilgrimage receive special attention; references to influential figures from the history of Christian spirituality such as Theresa of Avila and John Cassian are found frequently; Church and Holy Spirit form the sphere of understanding.

Within this theological ambience, Merton (1953:23) recommends that the Scriptures be meditated on, in silence as much as in Psalm song. The word of God is the primary orientation of the mystic in seeking the divine will, but with the typical or hidden meaning of the Bible text which can be revealed only by God (Merton 1953:28-29). The Psalms do offer practical daily wisdom (Merton 1953:27), but extracting the sense of Scripture is no straightforward matter without possibilities of misinterpretation, for instance in allegory (Merton 1953:30-38). Yet, engagement with the Psalms is of profound importance, since the mystical or revealed sense of Scripture is what the Church "studies ... lives and is"

11 Here, though, one cannot help but suspect an editorial insertion: that the confession of ecclesial loyalty on this page was meant to ward off possible criticism of remarks on the interpretation of the Scripture and the Church in especially chapter 3, titled "Meanings in Scripture". 
(Merton 1953:37). Symbolism in the Psalms (though not analysed in any detail) and the voice of the church fathers (Merton 1953:53-64 \& 73-77, respectively) lend the Psalms their transformative nature. This occurs through the identification of the reader with Christ, in suffering and in joy - not through a Christological interpretation of the Palms, but as a mystical union of the believer with Christ while reading the Psalms (Merton 1953:127130). Experience, rather than exegesis, is the theological key here.

The vitality of the Psalms therefore lies therein that, as much as they spoke to ancient Israel, they speak to the modern Church (Merton 1956:8-9). The challenge that the Bible poses for understanding is not about its shattering its readers' preconceptions and divisiveness, but about the readers finding wholeness in faith and in humanity (Merton 1972:13-15).

\section{Weber, Werkbuch Psalmen III. Theologie und Spiritualität des Psalters und seiner Psalmen}

A Swiss pastor and academic, Weber's volume under discussion here lies in a stream of publications which, in retrospect (and fully visible in the text of Werkbuch Psalmen III), prepared the way for it:

- Weber, B 2001. Werkbuch Psalmen I. Die Psalmen 1 bis 72. Stuttgart: Verlag W Kohlhammer.

- Weber, B 2003. Werkbuch Psalmen II. Die Psalmen 73 bis 150. Stuttgart: Verlag W Kohlhammer.

- As contributor to: Heinrichs, W \& Haubeck, W (Hrsg.) 2007. Geistlich leben: Spiritualität in Gemeinde und Alltag. Witten: Bundes-Verlag.

His Werkbuch Psalmen III. Theologie und Spiritualität des Psalters und seiner Psalmen (Weber 2010) is about to be published in English as:

- Weber, B 2015. Theology and Spirituality of the Psalms. Winona Lake, In.: Eisenbrauns.

This kind of thorough academic grounding that prepared the way for Werkbuch Psalmen III... (Weber 2010), is constitutive also of the way each of these volumes has been written. In Werkbuch Psalmen III... (Weber 2010) we see it too, as by far the most voluminous, thoroughly researched and structurally most integrated of the three books under discussion. Here intellect and faith meet, with the former much more on the foreground than in the previously-discussed two works; not in the sense that the intellectual aspect predominates all -Weber's orientation faith is too pronounced for that; however, this aspect is much less overtly present than in Merton's work discussed above.

The commitment to a faith orientation is demonstrated in various ways in Weber's volume. It is stated directly in the introduction that he intends to combine scholarship and theology with spirituality and practice (Weber 2010:5). The Bible sciences indeed ought to serve church, school and society (cf. Weber 2014). This is then demonstrated by way of studies on selected Psalms, with the book at the same time structured to reflect considerably on aspects of liturgy in church and nature (Weber 2010:55-98), the relationship between God and humanity (Weber 2010:98-133), and the oft-recurring themes in Old Testament scholarship of kingship and prophecy, wisdom, and prayer (respectively, Weber 2010:155177, 177-200 \& 200-213). A both substantial and substantive closing section (Weber 2010:213-286) reflects on the relationship between the Psalms, history and spirituality in 
what should in my opinion become standard reading for all interested in the intersection between Bible and faith.

As example, the discussion of Psalm 1 (Weber 2010:29-38) demonstrates the specific manner in which exegesis and spirituality come to the fore in Weber's volume. A translation of Psalm 1 is followed by a thorough discussion of its key term, Torah, which is constitutive for understanding this text among the Torah psalter - Psalm 1, 19, 119, and perhaps more - and within the very active theological debate within post-exilic Israel as reflected across the Old Testament collection (Lombaard 2014a:472-488). Other key terms and their implications are discussed, as well as a central difficulty in this Psalm: the way the just and unjust are juxtaposed - a philosophical and ethical question with this Psalm which should never be skirted. A brief indication of the reception of Psalm 1 closes the discussion, with a concluding sentence which, in non-directive mode, makes the point that the way of Yahweh in Psalm 1 is therefore something that transcends time, across the centuries. The implication is clear, though left unsaid: the way of God should in turn be sought and followed by modern believers.

To be expected as a reaction to such an analysis, is the criticism that here we have too little spirituality. Where is the explication or application? To which the answer would be, in the mode of Calvinist application, often: by implication. By understanding the text in these aspects outlined above, the reader's faith is in/formed. The fuller implications are left, again in non-directive mode, to be discerned by the contemporary believer. The fact that this is done with particularly Psalm 1, is indeed poetic, since that is precisely the way Psalm 1 exerts its influence on the Psalms collection and within the theological debate within which it stands: by implication (cf. Lombaard 2000:506-514). This isbecomes even clearer when read against the backdrop of the Psalms-history - spirituality reflection in the closing section of this volume (particularly, here, Weber 2010:240-252).

\section{All Together Now}

As just the briefest comparison of these three works, the immediately obvious difference between the works discussed is their general orientation, which may be characterised in broad terms as, respectively, esoteric, DePrince; spiritual, Merton; and exegetical, Weber. On a sliding scale of - on one side - historical cognizance being taken of the text, to - on the other side - interest in application of the Psalms to the lives/faith lives of the intended readership, the DePrince work shows no inclination to the former, and a full orientation to the latter. The that of what may be termed the contemporary efficacy of the Psalms has prime focus. Merton's discussed work shows awareness of the difficulties of Bible interpretation, and proceeds without exegetical demonstration to sketch ways in which the Psalms may be experienced within life, most particularly monastic faith life. The how of the influence of the Holy Word on believers' lives is outlined in experiential aspects. Weber's approach takes great care exegetically to understand the texts in their ancient contexts, and then to imply only that there are parallel aspects to what happens in the text to the lives/faith lives of the faithful. The how is not reflected upon; the that is assumed, and the manner in which is left to be deduced.

The appeal of these three approaches would be quite dissimilar; few people would be attracted to these three books in equal measure. Clearly, three quite different spiritualities are at work here. Equally, three quite different spiritualities are at work here - faith shows its presence as constitutive to all three approaches. Though apparent in distinctive ways, awareness of (the possibility of) the presence of the Above-human in the Psalms, and 
through the Psalms ${ }^{12}$ in the lives/faith lives of people today, is present in all three of these works.

Not to beg the question, then: is critical evaluation of these three approaches possible? In this presentation, a preference for a more historically oriented grounding as point of departure, from which of course should then be continued to the contemporary-experiential, has been implied throughout. That reflects, however, the evaluation of only one interpreter, which is moreover based on the admittedly limited criteria of valid historically-oriented exegesis and valid experientially-oriented explication/application (criteria which are, and must always remain, themselves open to debate). Here, much reflection is still required: can evaluative judgments be made, and if so, how, in judging relative merit amongst spiritualities?

\section{Conclusion: Hol(e)y Texts; Hol(e)y Lives}

"After all, to say that God or any other thing is wholly other is, strictu sensu, impossible" (Caputo 1998:191). We require assistance to say the unsayable - even though what we then say about the divine is, as we know in the same instant, better unsaid. Perhaps therefore silence remains the most valid human response to the Holy (cf. Lombaard 2012b:929-951; contra Karle 2004:147). When the faithful have dared to speak of God, and of themselves coram Deo, many ways have presented themselves, with re-saying the holy words from the Scriptures as a midway of sorts between assertion and silence. Praedicatio verbi Dei est verbum Dei - here, however, not understood as Bullinger had intended, that sermons by the ordained are God's words, nor as reinterpreted by Barth, that preachers are God's messengers (cf. Karle 2004:140-147), but meant rather as Von Rad (1962:134) understood biblical preaching: "(d)ie legitimste Form theologischen Redens (ist) ... immer noch die Nacherzählung". In this respect, the heart of Reformed spirituality is fully accurately formulated by Karle (2004:146; cf. also Jonker 1989:288-299): "Die Reformatoren gingen davon aus, dass Gott primär im zirkulierenden Wort des Evangeliums erfahren wird" (emphasis added). If we are to talk of God or life coram Deo, then 'Praying the Psalms' (cf. e.g. Brueggemann 1982) or in some other form re-living/re-livening the Psalmistry, is perhaps as fully an act of faith as is humanly possible. Holy texts give word to holy lives; perhaps also: holy texts give life to holy lives.

\section{BIBLIOGRAPHY}

Barth, K 2010 [1922]. Der Römerbrief (2. Fassung). Zürich: Theologischer Verlag Zürich.

Bezuidenhout, LC 1995. Perspektiewe uit die Psalms wat lig werp op die wese van die geloofsgemeenskap. HTS Teologiese Studies / HTS Theological Studies 51/3:712-719.

Brueggemann, W 2002. Spirituality of the Psalms. Minneapolis: Fortress Press. Brueggemann, W 1982. Praying the Psalms. Winona, Minn.: Saint Mary’s Press.

12 The implication here is, the presence of the Holy (which would with greater ease be specified as "God" by Merton and Weber than, one suspects, DePrince would do reflexively). 
Caputo, JD 1998. God is wholly Other - almost: 'différance' and the hyperbolic Alterity of

God, in: Summerell, OF (ed.) The otherness of God. Charlottesville,

Va.: Th University Press of Virginia, 190-205.

DeBartolo, T 2002. God-shaped hole. Naperville, Ill.: Sourcebooks.

Delitzsch, F 1876. Biblischer Commentar über die Psalmen (neue ausarbeitung). Leipzig:

Dörffling und Franke.

DePrince, T 1994. The Secrets of attracting Good Luck. New York: The United Spiritual Temple Inc.

DePrince, T 1993. The mystical Key to the Psalms. New York: The United Spiritual Temple Inc.

DePrince, T 1986. Six Lessons in Crystal Gazing. New York: The United Spiritual Temple Inc.

De Villiers, P 1999. The Psalms and spirituality. Old Testament Essays 12/3:416-439.

Eaton JH 2004. Meditating on the Psalms. Louisville: Westminster John Knox Press.

Eaton, JH 2003. The Psalms: A historical and spiritual Commentary - with an Introduction and New Translation. London: T\&T Clark International.

Endres, JC 2002. Psalms and Spirituality in the $21^{\text {st }}$ century. Interpretation 56:143-154.

Firth, DG 2005. Hear, o Lord. A spirituality of the Psalms. Calver: Cliff College Publishing.

Firth, DG 2001. Stages of Prayer through the Psalms. South African Baptist Journal of Theology 10:1-9.

Fox, M 1982. Creative teaching. Educating for Transformation: The Spiritual Task. Horizons 9/1:74-80.

Gunkel, H 1917. Ausgewählte Psalmen. Göttingen: Vandenhoeck \& Ruprecht.

Habermas, J 2008. Secularism's Crisis of Faith: Notes on Post-Secular Society. New Perspectives Quarterly 25, 17-29.

Jonker, W 1989. Die eie-aard van die Gereformeerde spiritualiteit. Ned. Geref. Teologiese Tydskrif 30/3, 1989:288-299.

Karle, I 2004. "Praedicatio verbi dei est verbum dei”. Bullingers Formel neu gelesen. Evangelische Theologie 64/2:140-147.

Krüger, K 2006. Sounding Unsound. Orientation into Mysticism. Pretoria: Aurora Press.

Kuhn, T 1970. The Structure of Scientific Revolutions (2nd ed.). Chicago: University of Chicago Press.

Le Roux, J 2003. Augustine and the Study of the Psalms. (Or: the Psalms as a Book of Enjoyment and as an Answer to a Question). Old Testament Essays 16/3:624-633.

Le Roux, J 1993. The Nature of Historical Understanding (or Hermeneutics and History). Studia Historiae Ecclesiasticae XIX/1:35-63.

Le Roux, JH 1993a. A Story of Two Ways. Thirty Years of Old Testament Scholarship in South Africa (Old Testament Essays Supplement Number 2). Pretoria: Verba Vitae. Liebert, E 2002. The role of Practice in the Study of Christian Spirituality. Spiritus 2/1:30-49. 
Lombaard, C 2015a. Deus ex Machina? Religious Texts, Spiritual Capital and Inequalities: In Continuation of a current Debate (a response to colleague Farisani). Verbum et Ecclesia 3611, Art. \#1378, http://dx.doi.org/10.4102/ ve.v36i1.1378.

Lombaard, C 2015b. Godness, Goodness and Scriptures: the Interlinked Societal Experience of Faith, Morality and the Bible. Presentation at LCC International University, Klaipeda, Lithuania, 17 April 2015.

Lombaard, C 2015c. Biblical Spirituality and Transformation. Presentation at the Marburger Bibelseminar (www.mbs-akademie.de), 7 November 2012, to be published in the In die Skriflig / In Luce Verbi special edition for JA du Rand, 2015.

Lombaard, C 2015d. Discernment and Biblical Spirituality - an Application: Discernment in the Milieu and Wake of Nehemiah 8. Journal for the Study of Religion, May 2015 (forthcoming).

Lombaard, C 2014a. Mysticism and Understanding: Murmurs of Meaning(fulness) Unheard Silences of Psalm 1. Old Testament Essays (special edition for Harry van Rooy), 27/2:472-488.

Lombaard, C 2014b. Discernment: Context, Orientation, Definition. Ekklesiastikos Pharos Dec. 2014 (special edition for Ben Hendrickx).

Lombaard, C 2013. Faith Matters: Two Aspects of the present Theological Scene in South Africa. Studia Historiae Ecclesiasticae (special supplement for Cornél du Toit), XXXIX:113-128.

Lombaard, C 2012a. The Old Testament and Christian Spirituality. Theoretical and Practical Essays from a South African Perspective (International Voices in Biblical Studies 2). Atlanta, Georgia (USA): Society of Biblical Literature.

Lombaard, C 2012b. Om die Skrif tot stilte te bring... Gewaarwordinge oor Afrikaanse Bybelse spiritualiteit. Litnet Akademies (Godsdienswetenskappe), Desember 2012:9/3 , 929-951 / http://litnet.co.za/assets/pdf/Lombaard_9_3_GOW1.pdf

Lombaard, C 2000. By Implication. Didactical Strategy in Psalm 1. Old Testament Essays (Special Number for WS Prinsloo), 12/3:506-514.

Lombaard, C \& Froneman, J 2006. Three Broad Approaches to the Study of Religious Communication. Tydskrif vir Christelike Wetenskap / Journal for Christian Scholarship 42/3:151-158.

Marion, J-L 1992. Le phénomène saturé, in: Courtine, JF (ed.) Phénoménlogie et Théologie. Paris: Criterion, 79-128.

Merton, T 1972. Opening the Bible. London: Allen and Unwin.

Merton, T 1956. Praying the Psalms. Collegeville, Minn.: The Order of St. Benedict.

Merton, T 1953. Bread in the Wilderness. London: Burns and Oates.

Otto, R 1923. The Idea of the Holy: an Inquiry into the non-rational Factor in the Idea of the Divine and its Relation to the Rational ( $2^{\text {nd }}$ ed). Oxford: Oxford University Press.

Otto, R 1917. Das Heilige: über das Irrationale in der Idee des Göttlichen und sein Verhältnis zum Rationalen. Breslau: Trewendt \& Granier.

Pemberton, G 2012. Hurting with God: Learning to Lament with the Psalms. Abilene, Texas: ACU Press. 
Pemberton, G 2014. After Lament: Psalms for learning to trust again. Abilene, Texas: ACU Press.

Popper, KR 1963. Conjectures and Refutations. London: Routledge \& Kegan Paul.

Sipkema, E \& Lelyveld, K 2000. De Regel van de H Benedictus en het gebruik van de Psalmen. Een spiritualiteit van de Psalmen. Amsterdamse cahiers voor exegese van de Bijbel en zijn tradities 18:131-138.

Smith, BD 2012. The indescribable God. Divine Otherness in Christian Theology. Eugene, Or.: Pickwick Publications.

Sorg, R 1948. The spirituality of the Psalms. Orate Fratres XXII/12, Oct. 21, 1948:529-541.

Stuhlmueller, C 2002. The Spirituality of the Psalms. Collegeville, Minnesota: Liturgical Press.

Thiselton, AC 1980. The Two Horizons. Exeter: PaterNoster.

Van Huyssteen, JW 2006. Alone in the World? Human Uniqueness in Science and Theology. Grand Rapids: William B Eerdmans Publishing Company.

Von Rad, G 1962. Theologie des Alten Testaments (Band 1; 4. Auflage). München: Chr. Kaiser Verlag.

Waaijman, K 2004. Mystiek in de psalmen. Baarn: Uitgeverij Ten Have.

Waaijman, K 2002. Spirituality. Forms, Foundations, Methods. Dudley, Ma: Peeters.

Waaijman, K 2000. Spiritualiteit: vormen, grondslagen, patronen. Gent: Carmelitana.

Waaijman, K 1981. Psalmen by ziekte en genezing. Kampen: JH Kok.

Weber, B 2015. Theology and Spirituality of the Psalms. Winona Lake, In.: Eisenbrauns.

Weber, B 2014. “Wie ein Baum, eingepflanzt an Wasserrinnen ...” (Psalm 1,3). Beiträge zur Poesie und Theologie von Psalmen und Psalter für Wissenschaft und Kirche. Leipzig: Evangelische Verlagsanstalt.

Weber, B 2010. Werkbuch Psalmen III. Theologie und Spiritualität des Psalters und seiner Psalmen. Stuttgart: Verlag W Kohlhammer.

Weber, B 2003. Werkbuch Psalmen II. Die Psalmen 73 bis 150. Stuttgart: Verlag W Kohlhammer.

Weber, B 2001. Werkbuch Psalmen I. Die Psalmen 1 bis 72. Stuttgart: Verlag W Kohlhammer.

Welzen, H 2011. Contours of Biblical Spirituality as a Discipline, in: De Villiers, P \& Pietersen, L (eds.) 2011. The Spirit that inspires. Perspectives on Biblical Spirituality (Acta Theologica Supplementum 15). Bloemfontein: University of the Free State Press, 37-60.

Westermann, C 2011. Ausgewählte Psalmen. Göttingen: Vandenhoeck \& Ruprecht.

Wölber, H-O 1976. Der Königsweg der Spiritualität. Gedanken zur Frömmigkeit aus der Bibel. Evangelische Kommentare 9/12:724-727. 